\title{
IITANIUM MINERALS AS PROTOTYPES OF FUNCTIONAL MATERIALS WITH PRONOUNCED ELECTROMAGNETIC PROPERTIES
}

\author{
O. B. Kotova1, M. Harja ${ }^{2}$, L. N. Kotov ${ }^{3}$, A. V. Ponaryadov ${ }^{1}$ \\ ${ }^{1}$ Institute of Geology Komi SC UB RAS, Syktyvkar, Russia; kotova@geo.komisc.ru \\ 2 «Gheorghe Asachi» Technical University of Iasi, Romania; mharja@tuiasi.ro \\ ${ }^{3}$ Pitirim Sorokin Syktyvkar State University (SyktSU),Syktyvkar, Russia; kotovln@mail.ru
}

\begin{abstract}
In this paper new crystalline materials were developed with pronounced electromagnetic properties, derived from titanium minerals, on the base of Academician N. P. Yushkin concept about mineralogical geomaterial science.

Titanium minerals (rutile, anatase, ilmenite and others) are carriers of useful components (elements) and unique structures (nanotubes, nanocomposites and others). Titanium minerals were modified by hydrothermal method. The doping of $\mathrm{TiO}_{2}$ with silver was realized by solgel methods. The modified nanotubes of titanium dioxide by nitrogen and acid treatment were realized to study the influence of parameters (temperature, time of hydrothermal alkaline treatment, acid influence at washing, etc.) over nanomaterials properties.

The characterization of minerals and synthesis products was realized by scanning electron microscope (SEM), TEM, SEAD, EDAX, $\mathrm{X}$-ray fluorescence method, atomic force microscope (AFM), etc. We revealed the nature of the phases and the degree of crystallinity of $\mathrm{TiO}_{2}$-Ag nanocomposites with controlled particle sizes and electronic characteristics.

Nanotubes made of $\mathrm{TiO}_{2}$ are an alternative material for waveguides with high data flow rates, compared to the materials used in fiber technology.

Keywords: titanium minerals, nanotubes, nanostructures, nature-like technologies, electromagnetic properties.
\end{abstract}

\section{МИНЕРАЛЫ ТИТАНА КАК ПРОТОТИПЫ ФУНКЦИОНАЛЬЫЫМ МАТЕРИАЛОВ 〔 ВЫРАЖЕННЫМИ ЭЛЕЕТРОМАГНИтНЫМИ СВОЙСтвАМИ}

\author{
О. Б. Котова ${ }^{1}$, М. Харджа ${ }^{2}$, Л. Н. Котов ${ }^{3}$, А. В. Понарядов ${ }^{1}$ \\ ${ }^{1}$ Институт геологии Коми НЦ УрО РАН, Сыктывкар, Россия \\ ${ }^{2}$ Технический университет им. Г. Асаки, Яссы, Румыния \\ ${ }^{3}$ СГУ имени Питирима Сорокина, Сыктывкар, Россия
}

Показано развитие концепции минералогического геоматериаловедения академика Н. П. Юшкина на примере кристаллических веществ (синтезированных нанотрубок и других структурных нанообразований, производных по отношению к минералам титана) с выраженными электромагнитными свойствами.

Минералы титана (рутил, анатаз, ильменит и др.) являются носителями полезных компонентов (элементов) и уникальных структур (нанотрубок, нанокомпозитов и др.). Минералы титана были модифицированы гидротермическим методом. Легирование $\mathrm{TiO}_{2}$ серебром было выполнено с помощью золь-гелевого метода. Модифицирование нанотрубок диоксида титана путем обработки азотом и кислотой было выполнено для изучения влияния параметров (температуры, времени гидротермической обработки щелочью, влияния кислоты на промывку и т. д.) на свойства наноматериалов.

Информация о морфологии и химическом составе исходных минералов и продуктов синтеза получена с использованием сканирующего электронного микроскопа (SEM), TEM, SEAD, EDAX, рентгенофлюоресцентного метода, атомно-силового микроскопа (AFM) и др. Выявлены особенности фаз и степень кристалличности нанокомпозитов $\mathrm{TiO}_{2}$ - $\mathrm{Ag}$ с контролируемыми размерами частиц и электронными характеристиками.

Нанотрубки из $\mathrm{TiO}_{2}$ являются альтернативным материалом для волноводов с большими скоростями потока передаваемых данных по сравнению с используемыми материалами в волоконной технике.

Ключевые слова: минералы титана, нанотрубки, наноструктуры, природоподобные технологии, электромагнитные свойства.

\section{Introduction}

The concept of mineralogical geomaterial science by Academician N. P. Yushkin is gaining a new level of development today. The study of natural crystalline substances, including titanium minerals, allows identifying the features of conditions for their formation and the formation of physical and chemical properties, to evaluate the potential for their use in the industry $[12,25]$. The industry of nanosystems, technologies of production and diagnosing nanodevices and nanomaterials are included in the list of critical technologies and priority directions for the development of science, technology and technics in the Russian Federation.
When the size of structural elements decreases from $10^{-3}$ to $10^{-9} \mathrm{~m}$, the derivatives with respect to natural minerals can exhibit unique optical, electrical, magnetic, catalytic and other properties $[10,11,15]$. Nanostructured systems, based on monodisperse magnetic nanoparticles/nanocrystals, are promising as high-density data storage systems. A great contribution to the fundamental foundations of the processes of formation of nanostructured composite materials of natural and model synthetic mixtures was made by Prof. B. Goldin and co-authors $[5,6]$. The greatest attention of researchers is attracted by titanium-containing concentrates of natural raw and its synthetic model analogues, as well as products of 
their thermochemical processing, where signs of nanostructuring are revealed [6]. The titanium minerals are interesting because of their unique electrical and magnetic properties [9], including the values of the band gap, a large potential for capturing solar energy. Another important indicator of attractiveness of materials based on titanium minerals is their relatively low price, chemical and physical stability, nontoxicity. Semiconductor properties of substances based on titanium dioxide (rutile, anatase, ilmenite and others) make them potential materials as sensitizers for oxidation-reduction processes activated by light [23]. The doping of $\mathrm{Pt}, \mathrm{Au}$ and $\mathrm{Ag}$ atoms improves the photocatalytic activity of $\mathrm{TiO}_{2}$, reducing the recombination of electron-hole pairs [1]. The productivity of oxidation processes of $\mathrm{TiO}_{2}$ is influenced by various factors (degree of crystallinity, morphology and particle size). Therefore, the synthesis of titanium-based materials with target properties is still a challenge. In the field of nanoplasmonics, nanostructures (threads, fibers, tubes, layers), synthesized on the basis of natural minerals, are of particular interest. Previously, the authors of the work produced titanium dioxide nanotubes by hydrothermal synthesis [11, 14].

The purpose of the work: the search for new crystalline materials with pronounced electromagnetic properties on the basis of the features of nature-like technologies for the synthesis of nanotubes and other structural nanomaterials derived from titanium minerals.

\section{Methods and approaches}

Technologies for the synthesis of $\mathrm{TiO}_{2}$ nanotubes (samples HT0601 - HT0604, HT0701 - HT0708, HT0901 HT0904) are developed on the basis of methods and approaches of hydrothermal synthesis. They are adapted for the non-magnetic fraction of the gravity concentrate of the ilmenite-leucoxene ore from Pizhma deposit [14].

Technologies of production of $\mathrm{TiO}_{2}-\mathrm{Ag}$ nanocomposites (samples S1 and S2) are developed on the basis of the sol-gel method [4]. Information on the morphology and chemical composition of ore and synthesis products was obtained by Tescan VEGA 3 LMH scanning electron microscope (2017) with the Oxford Instruments X-Max energy dispersive attachment and the X-ray fluorescent method (Shimadzu XRF-1800). The analysis for crystalline structures for initial material and synthesized samples was carried out on the basis of the Shimadzu XRD-6000 diffractometer.

The roughness of surface of the samples (resolution 5 $\mathrm{nm}$ ), the shape and dimensions of the electric and magnetic micro- and nanoscale regions and their topology were determined by ARIS-3500 atomic force microscope (AFM), a magnetic power microscope (MPM) - modernized AFM, for which the semiconductor probe was replaced by a silicone probe with a CoCr magnetic coating. At the MPM in
2015 , the authors obtained images of magnetic granules, regions (resolution up to $20 \mathrm{~nm}$ ), and band domains in composite films of various compositions.

\section{Results and discussion}

Nanocomposites (nanostructured materials). The formation of titanium oxide by the sol-gel method includes binding of Ti monomers either by bridges (Ti-O-Ti) or hydroxides (Ti-OH-Ti). The nature of the phases and the degree of crystallinity of titanium nanostructures were revealed, which were analyzed by XRD method [13]. The peaks and relative intensity were taken from the JCPDS database: anatase (JCPDS 21-1272), rutile (JCPDS 21-1276), silver (JCPDS 04-0783) and silver oxide $\mathrm{Ag}_{2} \mathrm{O}$ (JCPDS 00 -076-139).

In all samples, the main peaks can be assigned to anatase by the following planes and corresponding $2 \theta$ angles: [101] (25.30); [38]; [200] (480); [105] (540); [204] (62.550) and [116] (690) [18]. Undoped $\mathrm{TiO}_{2}$ is anatase and a small amount of amorphous phase. The larger width and lesser sharpness of the peaks in sample S1 (as-synthesized) compared to $\mathrm{S} 2$ (calcined at $650{ }^{\circ} \mathrm{C}$ ) indicate that the first sample is less crystalline, has a smaller particle size than the other. In addition, $\mathrm{S} 1$ contains a crystalline phase of anatase in the main state, and S2 is a mixture of anatase and rutile, which is confirmed by the distinctive peaks at 27.5 and 360 due to rutile planes [110] and [101]. The lower position of the baseline for sample S2 indicates its higher degree of crystallinity compared to S1. SEM images and EDAX images for synthesized and calcined samples S1 and S2 were obtained. The results of EDAX analysis showed that after annealing the ratio of silver on the surface decreases, indicating its migration within the titanium oxide structure, as previously mentioned in the literature $[4,6]$.

Nanotubes. Anatase (or rutile) (3D, Fig. 1, A), reacting with an alkaline solution, is stratified (Ti-O bonds break) and layers are formed (2D, Fig. 1, B). The lateral and angular atoms of the layered structures should have a large number of broken bonds with sufficient energy to destabilize the entire two-dimensional system. Consequently, to close the broken bonds, the sample layers can be folded into nanotubes and form one-dimensional structures (1D, Fig. 1, C). The process of $2 \mathrm{D} \rightarrow 1 \mathrm{D}$ transition can lead to the formation of two types of nanotubes: concentric and nonconcentric (spiral) [13].

Fig. 2 and Fig. 3 show typical diffraction patterns of synthesized samples. Tubular twisting of atomic layers is accompanied by a noticeable expansion of shape of the peaks. Indices of the planes corresponding to the peaks of the diffraction pattern are given on Fig. 3. A typical peak for titanium dioxide nanotubes, observed in the region $2 \theta=10^{\circ}$, according [13], can be attributed to the of $\mathrm{H}_{2} \mathrm{Ti}_{3} \mathrm{O}_{7}$ or $\mathrm{Na}_{\mathrm{x}} \mathrm{H}_{2-\mathrm{x}} \mathrm{Ti}_{3} \mathrm{O}_{7}$ crystals. This peak belongs to plane (200) with the interlayer distance $0.96 \mathrm{~nm}$ cor-
A

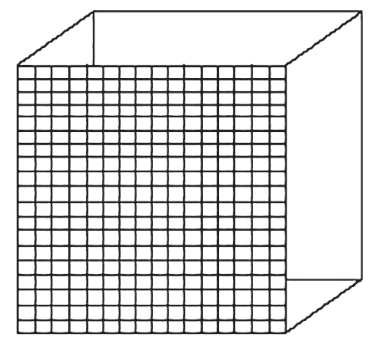

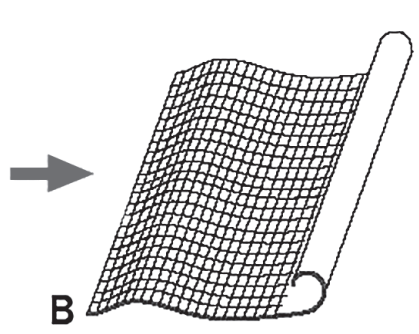
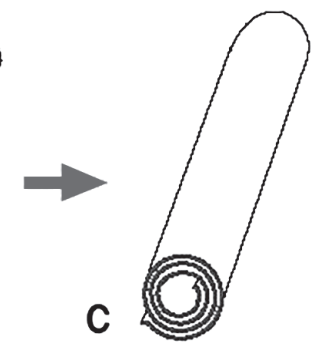

Fig. 1. The process of titanium dioxide nanotubes formation

Рис. 1. Процесс образования нанотрубок диоксида титана 


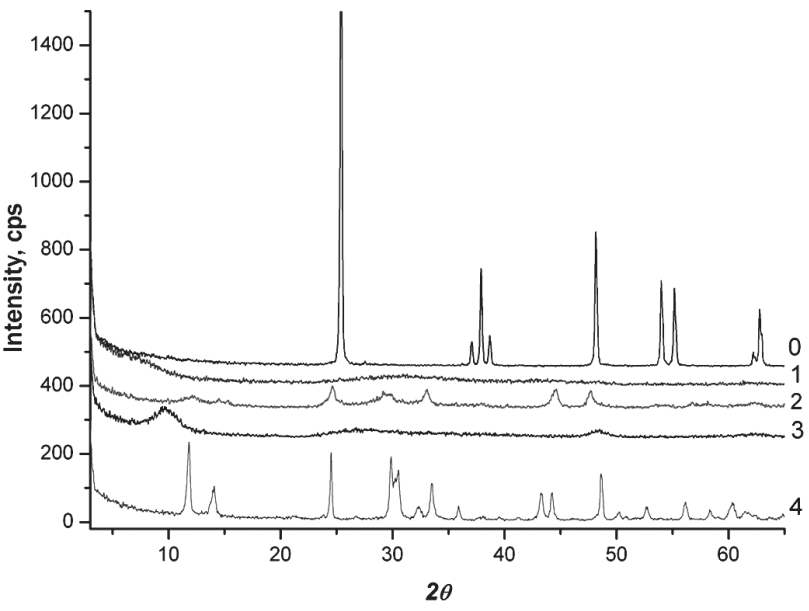

Fig. 2. Diffraction patterns of initial material (0), samples HT0601 (1), HT0602 (2), HT0603 (3), HT0604 (4)

Рис. 2. Дифрактограммы исходного материала (0), образцов HT0601 (1), HT0602 (2), HT0603 (3), HT0604 (4)

responding to the distance between two neighboring $\mathrm{TiO}_{6}$ octahedra forming nanotube walls. It is also noted that this peak can be absent in the case of decreasing $\mathrm{pH}$ during the acid treatment. In our case, a significant decrease of the intensity of this peak occurred after the acid treatment (samples of HT0707 and HT0708, $0.1 \mathrm{M} \mathrm{HCl}$ treatment). Thus, the alkaline treatment of rutile results in to a restructuring at the nanolevel - the formation of titanium dioxide nanotubes.

The TEM-images of the synthetized materials (Fig. 4), allowed specifying data on their structure, as well as evaluating the degree of influence of various synthesis parameters (temperature, duration of hydrothermal alkaline exposure, acid influence at washing) on their morphology.

We determined influence of duration of hydrothermal alkaline treatment on the geometric parameters of forming titanium dioxide nanotubes. The increase in the reaction time from 24 (Fig. 4, A) to $72 \mathrm{~h}$ (Fig. 4, B) leads to decreasing outer and inner diameters, as well as the interlayer gap of the obtained nanotubes. It should be noted that the interlayer gap is large, according to the X-ray diffraction data, compared to that obtained by the transmission electron microscopy, which can be explained by the presence of water molecules in the interlayer gaps. The number of layers in the walls is the same in this case.

On the electron diffraction pattern of the nanostructured samples, the reflexes of only (101) and (004) planes are clearly distinguished. Blurring of the diffraction pattern in comparison with the anatase electron diffraction pattern,

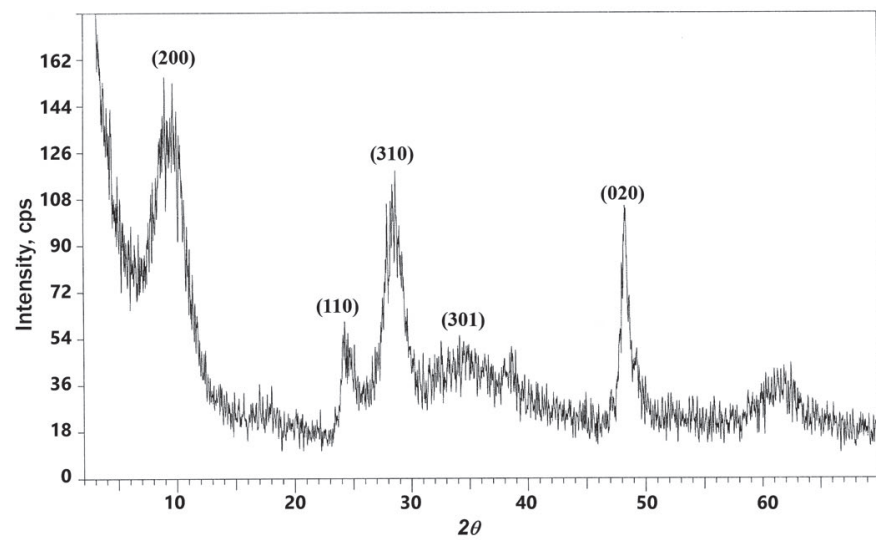

Fig. 3. Diffraction pattern HT0701

Рис. 3. Дифрактограмма образца НТ0701 can be attributed to the formation of tubular materials at nanoscale.

Electromagnetic and electronic properties of titanium minerals. UV spectra were used to determine the band gap of the initial material and the obtained samples. A shift of the absorption band toward the visible radiation was observed, when nanotubes were formed. However, according to the spectra shown in Fig. 5, such a shift is not observed or the absorption band is shifted to the short-wave region (sample HT0901).

There are two formulas to calculate the band gap. The first [20]:

$$
E_{g}=\frac{1240}{\lambda_{g}},
$$

where $\lambda_{\mathrm{g}}-$ intersection point extrapolation straight line with abscissa axis (Fig. 5, A).

The second formula [24] is based on the relation between the adsorption coefficient $\alpha$ and the photon energy hv:

$$
\alpha=\frac{B_{i}\left(h v-E_{g}\right)^{2}}{h v},
$$

where $\mathrm{B}_{\mathrm{i}}-$ adsorption constant for indirect transitions. For further calculations it is convenient to construct $\sqrt{h v \alpha}=f(h v)$ dependence with extrapolation of the linear part of the spectrum to zero. Since the adsorption coefficient $\alpha$ is proportional to the spectral absorption $\mathrm{A}$, then we can proceed to the construction of $\sqrt{h v A}=f(h v)$ dependence. The intersection of the extrapolation straight line (Fig. 5, B) with the abscissa axis gives the desired value of the band gap. The obtained values are shown in Table.

Band gap

Ширина запрещенной зоны

\begin{tabular}{|c|c|c|}
\hline \multirow{2}{*}{ Sample } & \multicolumn{2}{|c|}{ Band gap (eV) } \\
\cline { 2 - 3 } & Formula (1) & Formula (2) \\
\hline HT0801 & 3.35 & 3.075 \\
\hline HT0802 & 3.35 & 3.075 \\
\hline HT0901 & 3.48 & 3.125 \\
\hline Anatase & 3.35 & 3.1 \\
\hline
\end{tabular}

Titanium dioxide occurs in many polymorphs, but the most important ones are anatase and rutile. These two polymorphs are wide-gap semiconductors $\left(\mathrm{E}_{\mathrm{a}}=3.23\right.$ and $\mathrm{E}_{\mathrm{a}}=3.02 \mathrm{eV}$, respectively), so they can support photocatalytic reactions in the presence of visible light [22].

A convenient strategy to increase the absorption of visible light is to incorporate noble metal nanoparticles into titanium oxide. Such additives as $\mathrm{Pt}, \mathrm{Pd}, \mathrm{Au}, \mathrm{Ag}$ improve the photocatalytic efficiency of $\mathrm{TiO}_{2}$, preventing recombination of the electron-hole pair [23]. Silver is suitable, it is non-toxic and much cheaper than other mentioned noble metals, improving the bioactivity of $\mathrm{TiO}_{2}$, especially when treated with water, because of its own antibacterial activity against various microorganisms [10].

Previously, it was shown that the higher activity of samples of doped titanium dioxide compared to pure $\mathrm{TiO}_{2}$ can be explained by the contribution of silver compounds [8], which have a very small band gap $(1.3 \mathrm{eV})$ and form boundaries due to $\mathrm{Ag}_{2} \mathrm{O}$ aggregation on carrier. Calcination generates an appropriate ratio between anatase and rutile, which plays an important role in optimizing the electron hole of the 

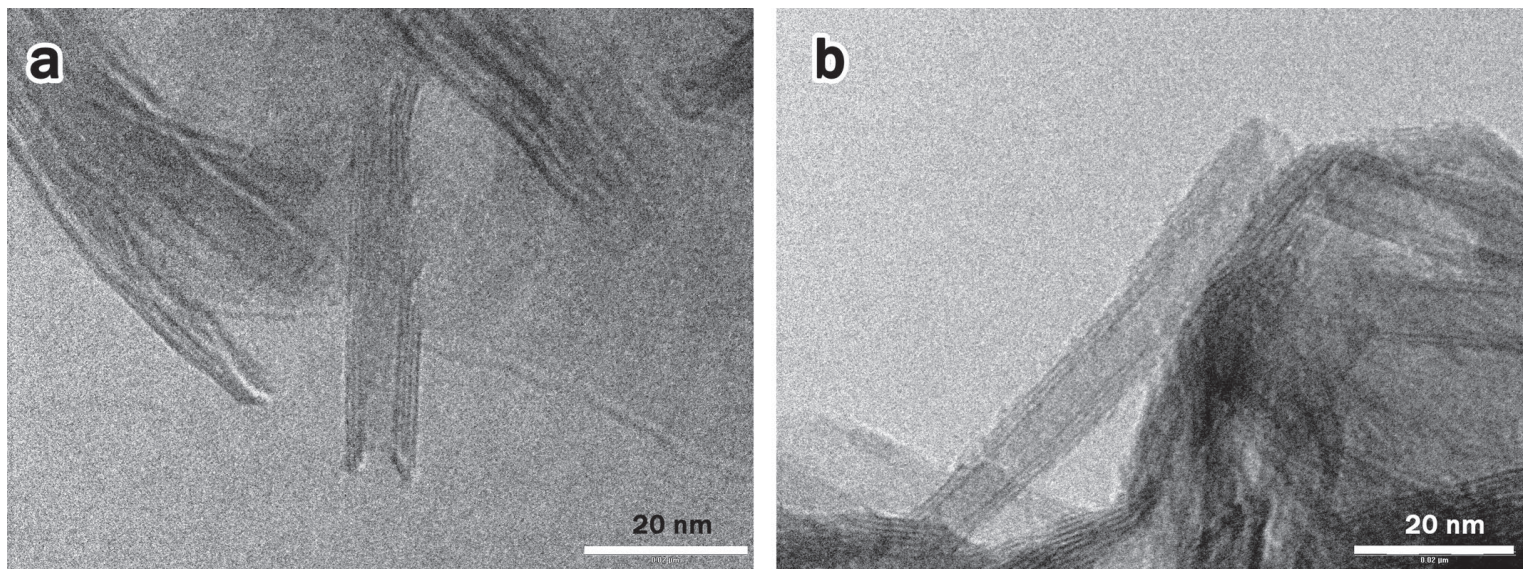

Fig. 4. TEM image of nanostructured $\mathrm{TiO}_{2}$ (sample HT0701, synthesis time $\mathrm{A}-24 \mathrm{~h}, \mathrm{~B}-72 \mathrm{~h}$ ). The scale corresponds to $20 \mathrm{~nm}$

Рис. 4. ТЕМ-изображения наноструктурированного $\mathrm{TiO}_{2}$ (образец НТ0701, А - время синтеза 24 ч, В - время синтеза 72 ч). Шкала соответствует 20 нм

pairs. The position of the energy levels of the valence band and the conduction bands of the two phases promotes the migration of the advanced electron from the anatase conduction band to the rutile conduction band, instead it allows recombination [19].

We also modified nanotubes of titanium dioxide by nitrogen, which was accompanied by a shift in intrinsic absorption to the visible light zone. The obtained samples were annealed at different temperature $(550-873 \mathrm{~K})$.

Fig. 6 shows UV spectra of the studied samples before and after the modification. The shift of the absorption band is clearly visible toward increasing the wavelength. In addition to this displacement, a so-called «shoulder» occurs in the region of 400-773 $\mathrm{nm}$ (indicated by an arrow), which is associated with electronic transitions from $2 p$ level of nitrogen atom to conduction band [7]. This shoulder becomes more pronounced with increasing annealing temperature in nitrogen flow.

The band gap was calculated using dependencies $\sqrt{h v A}=f(h v)$ [24]. The change made $1 \mathrm{eV}$ (3.1 for anatase and $2.1 \mathrm{eV}$ for nitrogen modified nanotubes). The energy of $2.1 \mathrm{eV}$ corresponded to radiation, with a wavelength $590 \mathrm{~nm}$.

According to the literature [7], the degree of isomorphous substitution of sodium atoms in the crystal-substrate structure is proportional to the annealing temperature. However, our studies of the temperature stability of modified samples showed that the increase in temperature above $673 \mathrm{~K}$ leads to the breaking of the tubular structure and for-

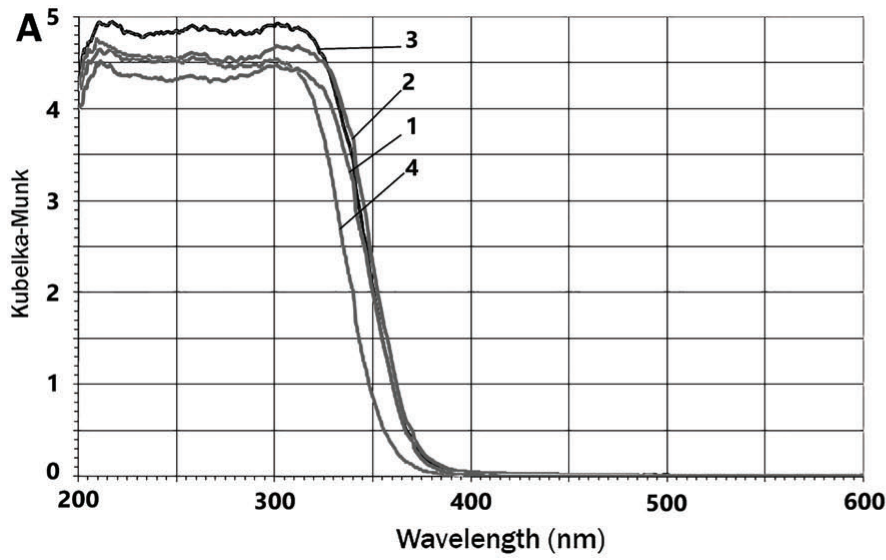

mation of aggregated anatase particles. This determined the upper limit of the temperature range permissible for annealing the samples after interaction with ammonium hydroxide in nitrogen flow. Fig. 7 presents images of nanostructured sample HT0903 before and after modification (annealing at $623 \mathrm{~K})$.

Fig. 8 presents some blurring of the image: the electron beam is partially scattered by the surface of the sample, which is confirmed by comparing the electron diffraction patterns of the original sample HT0903 and the sample after the modification. At the electron diffraction pattern of a nanostructured sample after isomorphic substitution, the diffraction pattern is blurred. This may be related to the presence of residual ammonium hydroxide on the surface of the sample.

Wave properties of $\mathrm{TiO}_{2}$ nanostructures, application. $\mathrm{TiO}_{2}$-based nanostructures (filaments, fibers, single and multilayer tubes, layers, nanocomposites) and their electromagnetic properties (UV absorption spectra) are very interesting. The previous electron microscopic images of synthesized $\mathrm{TiO}_{2}$ nanotubes allowed determining their dimensions: diameter 70-100 $\mathrm{nm}$ and length $2-5.5 \mathrm{mcm}$ [21]. Considering the nanotube sizes, it is possible to note that single- and multilayered $\mathrm{TiO}_{2}$ nanotubes can be used as guide systems (waveguides) of electromagnetic waves (EMW) of UV range $(\lambda=10 \div 380 \mathrm{~nm})[2,3]$. Intervals $\lambda$ for transparency bands should not include absorption bands. The observed absorption peak of UV radiation in the wavelength range

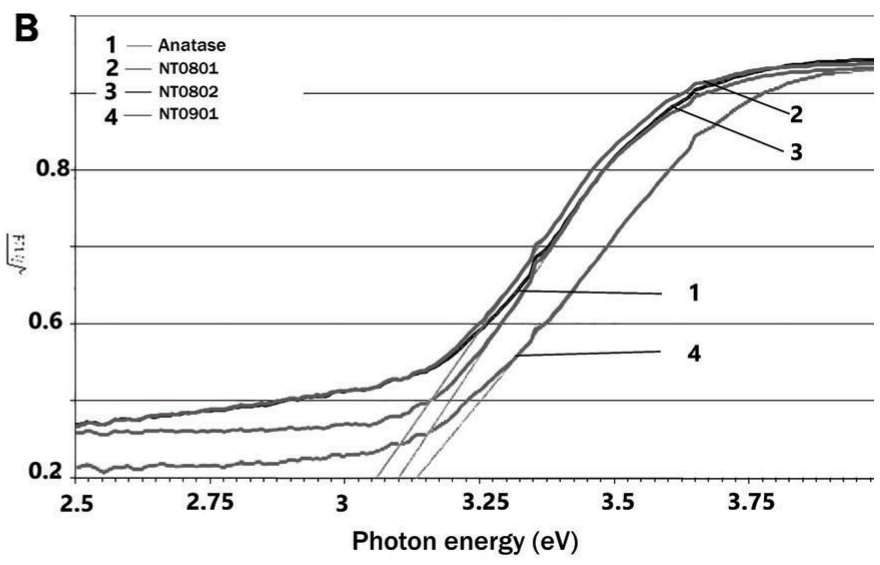

Fig. 5. UV spectrum of initial anatase and synthesized samples (A); determination of the band gap (B)

Рис. 5. Спектры поглощения ультрафиолетового излучения исходного анатаза и синтезированных образцов(А); определение ширины запрещенной зоны (B) 

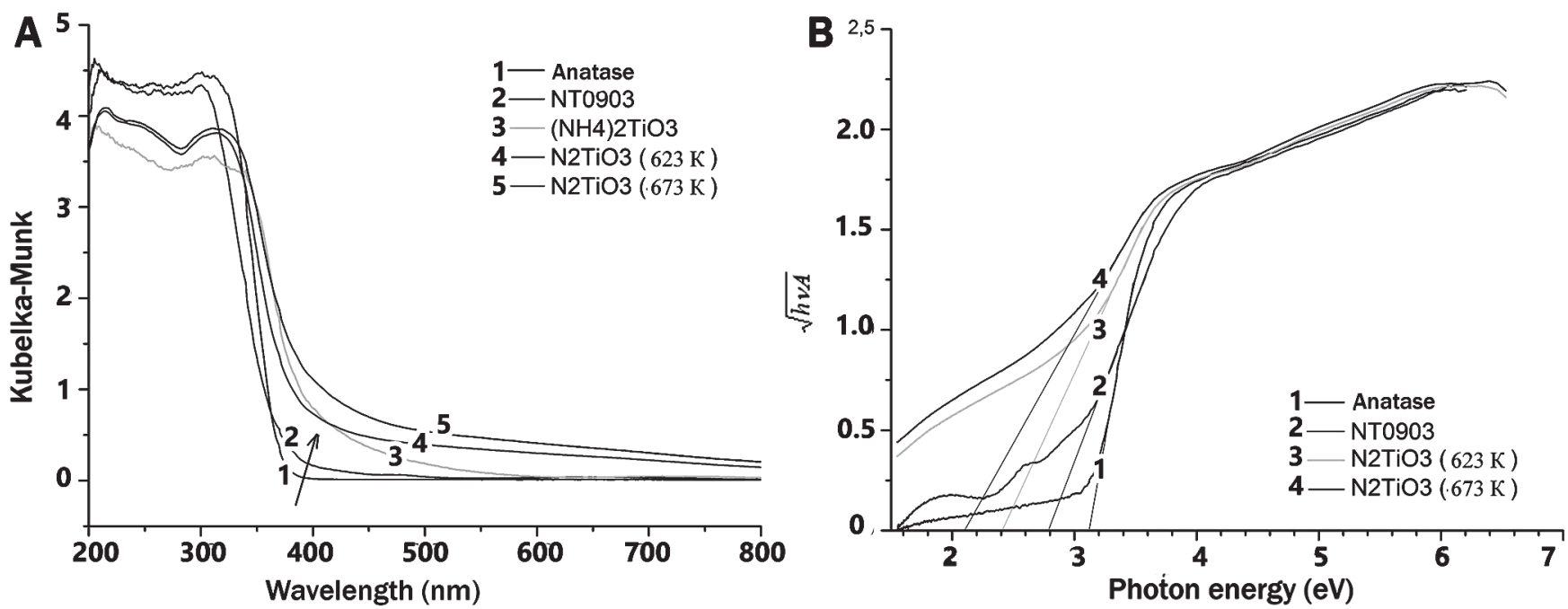

Fig. 6. UV spectra of diffuse reflection of anatase and nanostructured $\mathrm{TiO}_{2}$ (sample HT0903) before and after nitrogen modification (A); determination of the band gap (B). Annealing temperature is given in parentheses

Рис. 6. УФ-спектры коэффициента диффузного отражения анатаза и наноструктурированного ТiО 2 (образец НТ0903) до и после модифицирования (А); прямые для определения ширины запрещенной зоны (B). В скобках указана температура отжига соответствующих образцов

$\lambda=200-380 \mathrm{~nm}$ shifts the maximum wavelengths allowed for waveguides, i.e. they should be less than $\lambda=200 \mathrm{~nm}$. The refractive index $\mathrm{n}$ for wavelengths of the UV range is 2.6 [17, 21], the value of which determines the geometry of EMW propagation in $\mathrm{TiO}_{2}$ nanotubes. To realize the minimum energy loss condition propagating in the wave tube, the angles of incidence of EMW on the waveguide wall must exceed the limiting angle. In this case, the condition for total internal reflection of the EMW is fulfilled. Then the value of the limiting angle of incidence of EMW on the walls of $\mathrm{TiO}_{2}$ nanotube should be $26^{\circ}$. The ratio of the diameter $d$ of the nanotube to the wavelength $\lambda$ will be determined by the following conditions. For EMW wavelengths much larger than the diameter of the waveguide (for $\mathrm{d} / \lambda<<1$ ), the presence of the waveguide walls will have a negligible effect on EMW propagation path [21]. In the other extreme, when the diameter of the waveguide is greater than the wavelength (for $d / \lambda>>1$ ), the role of nanotube walls, surrounding the wave propagation space, is also small: the wave propagates in a uniform air medium. The length of EMV $\lambda$ should corresponds to the wave interval between these two extreme cases. Transparency windows should also be included in this interval $\lambda$. This wave- length interval for synthesized $\mathrm{TiO}_{2}$ nanotubes corresponds to ultraviolet (UV) radiation with wavelengths $10 \times 200 \mathrm{~nm}$. All the above characteristics indicate that the obtained nanotubes on the basis of titanium dioxide can be used to simulate the propagation of EMF of UV band and can support further development of fiber technology, where quartz and quartzpolymer fibers with cross dimensions $50-125 \mu \mathrm{m}$ are now used, in which only IR waves can propagate [3]. $\mathrm{TiO}_{2}$ nanotubes are an alternative material for waveguides with much higher data flow rates, compared to the materials used in fiber technology.

\section{Conclusions}

Titanium minerals (rutile, anatase, ilmenite and others) are carriers of useful components (elements) and unique structures (tubes, nanocomposites and others). The nature of the phases and the degree of crystallinity of $\mathrm{TiO}_{2}-\mathrm{Ag}$ nanocomposites with controlled particle sizes and electronic characteristics were revealed. The conditions for the synthesis of nanotubes of titanium dioxide affect their morphology. It was shown that the inclusion of noble metal nanoparticles, such as $\mathrm{Pt}, \mathrm{Pd}, \mathrm{Au}, \mathrm{Ag}$, as well as nitrogen modifica-
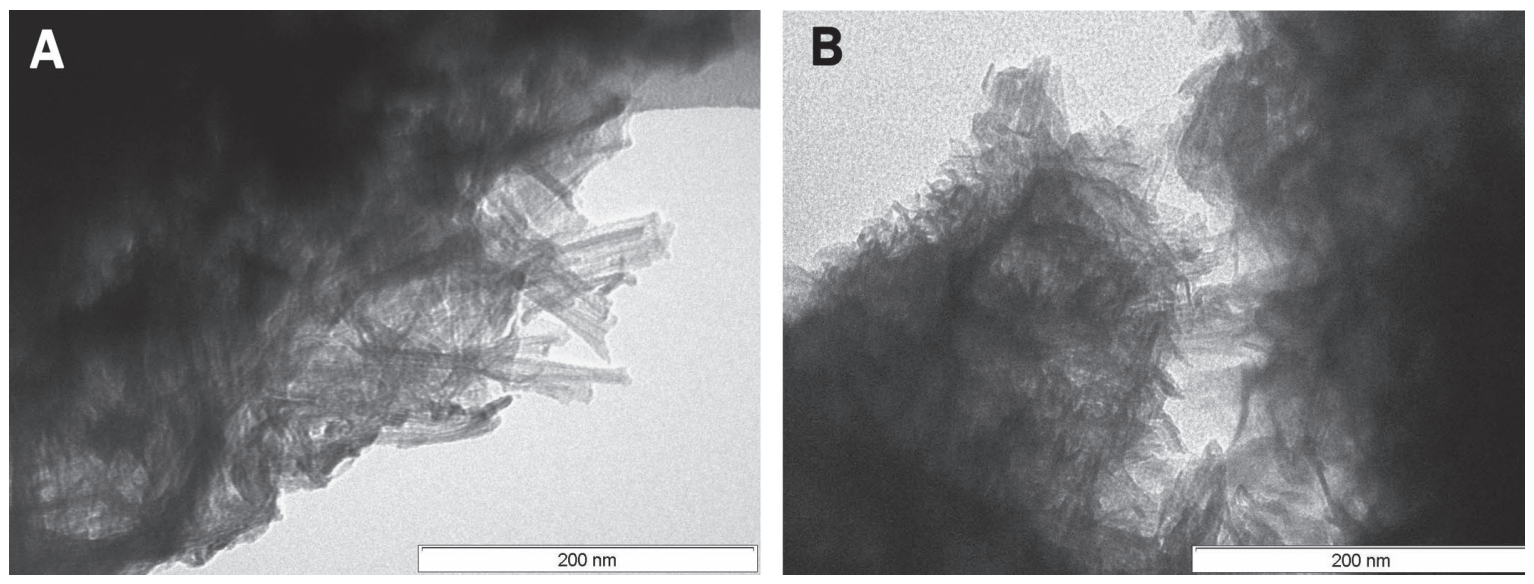

Fig. 7. TEM image of nanostructured $\mathrm{TiO}_{2}$ (A - initial sample HT0903, B - modified by nitrogen)

Рис. 7. ТЕМ-изображение наноструктурированного $\mathrm{TiO}_{2}$ (А - исходный образец НТ0903, В - модифицированный азотом) 


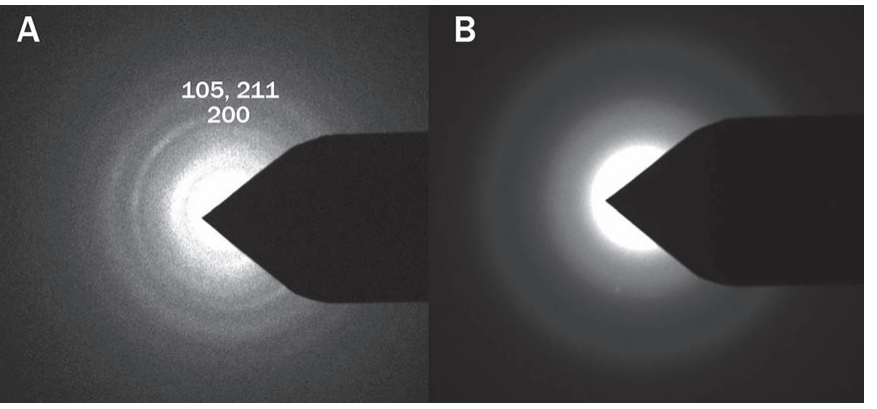

Fig. 8. Electron diffraction patterns of nanostructured $\mathrm{TiO}_{2}$ before (A) and after nitrogen modification (B)

Pис. 8. Электронограммы наноструктурированногоТіО 2 до (А) и после (В) модифицирования азотом

tion, was a convenient strategy for changing the band gap of rutile and anatase. Nanotubes, made of $\mathrm{TiO}_{2}$, are an alternative material for waveguides with high data flow rates, compared to the materials used in fiber technology.

The work was accomplished according to the research theme «Scientific basis for effective mining, the exploration and development of mineral resources base, development and implementation of innovative technologies, economic-geological zoning of Timan-Northern Ural Region» (GR No. AAAA-A17-117121270037-4) with the partial support of RFBR project (18-29-12113)

\section{References}

1. Amin A. S., Pazouki M., Hosseinnia A. Synthesis of $\mathrm{TiO}_{2}-\mathrm{Ag}$ nanocomposite with sol-gel method and investigation of its antibacterial activity against E. coli. Powder Technology, 2009, 196, pp. 241-245.

2. Belokopytov G.V., Rzhevkin K.S. i (Basics of radiophysics). Moscow: URSS, 1996, $256 \mathrm{pp}$.

3. Dmitriev S. A., Slepov N. N. Volokonno-opticheskaia tekhnika: sovremennoe sostoianie i novye perspektivy. 3-e izdanie. (Fiberoptical technics: modern state and future, $3^{\text {rd }}$ edition). Volokonnoopticheskaia tekhnika, 2010, 607 pp.

4. Duduman C., Cobos J., Caso de Los M., Harja M., Pйrez M., Castro C., Lutic D., Kotova O., CretescuI. Preparation and characterisation of nanocomposite material based on $\mathrm{TiO}_{2}-\mathrm{Ag}$ for environmental applications. Environmental Engineering and Management Journal, 2018, 17 (4), 2813-2821.

5. Goldin B. A., Grass V. E., Istomin P. V., Sekushin N. A., Ryabkov Yu. I. Razrabotka nanostrukturnykh keramicheskikh kompozitov. (Developing of nanostructured ceramic composites). Izvestiya Komi nauchnogo tsentra UrO RAN, Issue 1, 16, 2010, pp. 16-23.

6. Goldin B.A., Ryabkov Yu. I., Sitnikov P.A., Nazarova L.Yu., Tsvetkova E.V. Sintez titanatov so strukturoy sitinaki$t a$. Synthesis of titanates with sitinakite structure. Izvestiya Komi nauchnogo tsentra UrO RAN, 2011, 4 (8), pp. 29-34.

7. Huang L.H., Sun C., Liu Y.L. Pt/N-codoped $\mathrm{TiO}_{2}$ nanotubes and its photocatalytic activity under visible light. Applied Surface Science, 2007, 253, 7029-7035.

8. Jiang W., Wang X., Wu Z., Yue X., Yuan S., Lu H., Liang B. Silver oxide as superb and stable photocatalyst under visible and nearinfrared light irradiation and its photocatalytic mechanism. Industrial and Engineering Chemistry Research. 2015, 54, pp.832-841.

9. Kartal O. E., Turhan G. D. Determination of electrical energy cost of decolorization of C. I. Acid Orange 7 via $\mathrm{TiO}_{2}$-assisted photocatalysis under UV illumination in the presence of $\mathrm{H}_{2} \mathrm{O}_{2}$ Environmental Engineering and Management Journal, 2017, 16, pp.2045-2052.
10. Kotov L. N., Vlasov V. S., Turkov V. K., Kalinin, Yu.E, Sitnikov A. V. Influence of annealing on magnetic, relaxation and structural properties of composite and multilayer films. J. Nanoscience and Nanotechnology. 2012, V. 12, No.2, pp. 1696-1699.

11. Kotova O., Ozhogina E., Ponaryadov A., Golubeva I. Titanium minerals for new materials. IOP Conf. Series: Materials Science and Engineering. 2016, 123, 012025 (doi:10.1088/1757899X/123/1/012025)

12. Kotova O. B. Mineralogicheskoe geomaterialovedenie v svete razvitiia idei akademika $N$. P.Yushkina (Mineralogical geomaterial science developed from ideas of Academician N. P. Yushkin). Problemy i perspektivy sovremennoi mineralogii (Problems and prospects of modern mineralogy (Yushkin Memorial Seminar - 2014). Proceedings. Syktyvkar: Institute of geology Komi SC UB RAS, 2014, pp. 249-250.

13. Kotova O. B., Ponaryadov A. V. Nanotechnological mineralogy. Journal of Mining Science. 2009, V. 45, No. 1, pp. 93-98.

14. Kotova O. B., Ponaryadov A. V., Gцmze L. A. Hydrothermal synthesis of $\mathrm{TiO}_{2}$ nanotubes from concentrate of titanium ore Pizhemskoe deposit (Russia). Vestnik of Institue of geology Komi SC UB RAS. 2016a, No. 1, pp. 34-36.

15. Kuzmin D. A., Bychkov I. V., Shavrov V. G., Kotov L. N. Transverse-electric plasmonic modes of cylindrical graphene based waveguide at near-infrared and visible frequencies. Scientific Reports | 6:26915 | DOI: 10.1038/srep26915.

16. Ponaryadov A. V., Kotova O. B. Synthesis and properties of nanodisperse structures of titanium minerals by the example of anatase. Doklady Earth Sciences, 2009, V. 425A, No. 3, pp. 467-470.

17. RefractiveIndex.INFO. Database of refraction indices.

18. Sakurai K., Mizusawa M. X-ray diffraction imaging of anatase and rutile. Analytical Chemistry. 2010, 82, 3519-3522.

19. Scanlon D. O, Dunnill C. W., Buckeridge J., Shevlin S. A., Logsdail A. J., Woodley S. M., Catlow C. R. A., Powell M. J., Palgrave R. G., Parkin I. P., Watson G. W., Keal T. K., Sherwood P., Walsh A., Sokol A. A. Band alignment of rutile and anatase $\mathrm{TiO}_{2}$. Nature Materials. 2014, 12, pp. 798-800

20. Streethawong Th., Suzuki Y., Yoshikawa S. Synthesis, characterization, and photocatalytic activity for hydrogen evolution of nanocrystalline mesoporous titania prepared by surfactant-assisted templating sol-gel process. Journal of Solid State Chemistry. 2005, 329-338.

21. Tablitcy fizicheskikh velichin (c.641) (Tables of physical values). Ed. Academician I.K. Kikoin. Moscow: Atomizdat,1976, pp. 1008.

22. Tobaldi D. M., Pullar R. C., Gualtieri A. F., Seabra M. P., Labrincha J. A., Sol-gel synthesis, characterisation and photocatalytic activity of pure, $\mathrm{W}, \mathrm{Ag}$ and $\mathrm{W} / \mathrm{Ag}$ co-doped $\mathrm{TiO}_{2}$ nanopowders. Chemical Engineering Journal. 2013, 214, pp. 364-375.

21. Yin H., Yu K., Song C., Huang R., Zhu Z. Synthesis of AuDecorated $\mathrm{V}_{2} \mathrm{O}_{5}$ \& $\mathrm{ZnO}$ heteronanostructures and enhanced plasmonic photocatalytic activity. ACS Applied Materials \& Interfaces, 2014, 6, 14851-14860.

22. Yui H., Yu J., Cheng B., Zhou M. Effects of hydrothermal post-treatment on microstructures and morphology of titanate nanoribbons. Journal of Solid State Chemistry. 2006, 179, 349-354.

23. Yushkin N. P. Mineralogicheskie kriterii tekhnologicheskoi ocenki prirodnogo (i tekhnogennogo) syria dlia polucheniia iskusstvennykh mineralov (Mineralogical criteria of technological estimate of natural (and technogenic) raw for production of artificial minerals). Tekhnologicheskaia mineralogiia glavneishikh tipov mestorozhdenii (Technological mineralogy of main types of deposits). Leningrad: Nauka, 1987, pp. 9-14. 